Doktoral Ilmu Hukum, Fakultas Hukum, Universitas Lampung, Bandar Lampung, Lampung, Indonesia.

Volume1 Issue 1, January-June 2020: pp: 45-58

http://jurnal.fh.unila.ac.id/index.php/plr

P-ISSN: 2723-262X

E-ISSN: $2745-9306$

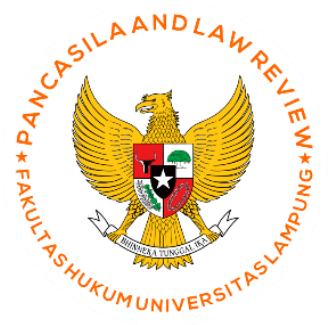

\title{
Pertimbangan Hukum Hakim Dalam Penjatuhan Sanksi Pembinaan Terhadap Anak Pelaku Pencurian dengan Pemberatan
}

\section{Legal Considerations of Judges in Imposing Coaching Sanctions Against Children of Thieves with Objection}

\author{
Vita Hestiningrum \\ vitha_c83@yahoo.com \\ Kejaksaan Tinggi Lampung \\ Erna Dewi \\ ernadewi00@yahoo.co.id \\ Fakultas Hukum Universitas Lampung \\ \& \\ Ahmad Irzal Fardiansyah \\ ahmad.irzal@fh.unila.ac.id \\ Fakultas Hukum Universitas Lampung
}

Submitted: Apr 16, 2020; Reviewed: Apr 30, 2020; Accepted: Mei 18, 2020

\begin{tabular}{|c|c|}
\hline Info Artikel & Abstrak \\
\hline $\begin{array}{l}\text { Kata Kunci: Pertimbangan Hakim; } \\
\text { Pembinaan Anak; Pencurian. } \\
\text { Keywods: Judges considerations; Child } \\
\text { Development; Theft. }\end{array}$ & $\begin{array}{l}\text { Tindak pidana yang dilakukan oleh anak } \\
\text { seharusnya ditempatkan di LPKA } \\
\text { sebagaimana dimaksud dalam undang- } \\
\text { undang peradilan anak, akan tetapi hakim } \\
\text { dalam putusan ini lebih memilih } \\
\text { menempatkan anak tersebut dalam } \\
\text { pembinaan pondok pesantren tentunya } \\
\text { dalam kasus ini hakim memiliki } \\
\text { pertimbangannya sendiri. Tulisan ini akan } \\
\text { mengkaji mengenai dasar pertimbangan } \\
\text { hukum hakim dalam menjatuhkan pidana } \\
\text { pembinaan terhadap anak pelaku tindak } \\
\text { pidana pencurian dengan pemberatan, }\end{array}$ \\
\hline
\end{tabular}


kesesuaian antara putusan Nomor: 8/Pid.Sus-Anak/2016/PN.Kot dengan tuntutan Jaksa Penuntut Umum, dan mekanisme pelaksanaan putusan Nomor: 8/Pid.Sus-Anak/2016/PN.Kot. Metode penelitian yang digunakan dalam penelitian ini menggunakan pendekatan normatif yakni penelitian normatif yang dilakukan dengan cara mengkaji undangundang dan teori-teori dasar. Adapun hasil penelitian yang didapatkan bahwa dasar pertimbangan hukum hakim dalam membuat putusan terhadap anak, bahwa didalam persidangan hakim melihat kedua anak yang melakukan tindak pidana tersebut dikarenakan bukan karena faktor kejahatan melainkan karena faktor dominan kenakalan remaja dan juga kedua anak tersebut masih dapat diperbaiki mentalnya dengan memberikan kesempatan kepada kedua anak tentunya akan memberikan perlindungan bagi hakhaknya. Putusan hakim tidak sesuai dengan tuntutan jaksa dimana terdapat perbedaan yaitu: pertama, hakim tidak setuju dengan metode penerapan pemberian sanksi hukuman yang menempatkan anak di LPKA; kedua, kebebasan hakim dalam memberikan sanksi juga merupakan faktor terjadinya ketidaksesuaian antara tuntutan jaksa dengan putusan hakim; ketiga, dampak kerugian yang ditimbulkan oleh kedua anak tidak terlalu besar. Mekanisme dalam melaksanakan Putusan Nomor: 8/Pid.Sus-Anak/2016/Pn.Kot dimana hakim menjatuhkan pidana pembinaan dalam lembaga kepada kedua terdakwa berupa kewajiban mengikuti program pembinaan di Pondok Pesantren, sehingga metode pembinaannya mengikuti metode pembinaan di dalam pesantren. Berdasarkan hasil penelitian yang dilakukan disarankan kepada Jaksa Penuntut Umum lebih memperhatikan aspek kemanfaatan dalam memberikan sanksi pemidanaan kepada anak. Selain itu, sebaiknya pertimbangan hakim kedepannya harus bisa mencerminkan 

considerations of judges in imposing criminal guidance on children who are criminal offenders of theft with weighting, the suitability of decision Number: 8/Pid.Sus-Anak/2016/PN.Kot with the demands of the Public Prosecutor, and the mechanism for implementing the verdict. Number: $\quad 8 / P i d . S u s-A n a k / 2016 / P N . K o t$. The research method used in this research uses a normative approach, namely normative research which is carried out by examining the laws and basic theories. As for the results of the research, it was found that the basis for judges' legal considerations in making decisions against children, that in the trial the judge saw the two children who committed the crime not because of the crime factor but because the dominant factor of juvenile delinquency and also the two children could still be mentally corrected by giving opportunity for both children will certainly provide protection for their rights. The judge's decision was not in accordance with the prosecutor's demands where there were differences, namely: first, the judge did not agree with the method of imposing penalties that put children in LPKA; second, the judge's freedom to impose sanctions is also a factor in the incompatibility between the prosecutor's demands and the judge's decision; third, the impact of the harm caused by the two children was not too big. The mechanism for implementing the Decision Number:8/Pid.Sus- 
Anak/2016/Pn.Kot where the judge handed down the punishment of coaching in the institution to the two defendants in the form of an obligation to participate in a coaching program at the Islamic Boarding School, so that the guidance method followed the guidance method in the pesantren. Based on the results of the research conducted, it is recommended that the Public Prosecutor pay more attention to aspects of benefit in imposing criminal sanctions on children. In addition, the judge's future considerations should reflect justice and progressive steps.

\section{A. Pendahuluan}

Indonesia adalah negara hukum yang sistem penyelenggaraan negaranya didasarkan oleh suatu aturan hukum. Hukum merupakan suatu aturan bagi masyarakat yang didalamnya terdapat atura-aturan yang biasanya berbentuk perundangan-undangan, di setiap negara memiliki hierarkinya masing-masing, ${ }^{1}$ Selain peraturan perundang-undangan yang menjadi dasar aturan hidup manusia, pancasila sebagai falsafah negara juga mengandung nilai-nilai dasar sebagai pedoman bagi negara untuk menjalankan sistem pemerintahannya guna menciptakan keadilan dan kesejahteraan bagi masyarakat. Milihat kondiso sekarang manusia semakin hari semakin berkembang dan semakin derasnya arus informasi dibidang digital juga turut menyokong pergeseran moral seluruh lapisan masyarakat terutama anak yang masih dalam proses untuk mencari jati diri, sehingga tidak sedikit yang cenderung membawa anakanak tersebut untuk berbuat kejahatan yang merugikan orang lain ataupun dirinya sendiri. Hal tersebut membuat anak kadang terpaksa harus berhadapan dengan hukum. ${ }^{2}$

Masalah kenakalan anak sekarang ini tetap merupakan persoalan yang krusial di Indonesia. ${ }^{3}$ Gaya hidup yang juga turut menetukan peran dalam menggeser sosial kehidupan masyarakat karena pengaruhnya begitu besar sehingga apapun yang dilihat dan ditiru oleh anak-anak tidak memiliki filter sama sekali dalam penyerapan informasi mana yang baik dan mana yang benar. ${ }^{4}$ Kejahatan merupakan suatu dampak negative akibat adanya perkembangan zaman, terlebih zaman sekarang anak dapat dengan mudah melakukan suatu tindak kejahatan. ${ }^{5}$ Masa anak merupakan masa yang sangat rawan melakukan suatu tindak pidana. ${ }^{6}$ Seperti berbagai kasus kejahatan kekerasan seksual, sering terjadi terhadap anak di seluruh

\footnotetext{
${ }^{1}$ Shandi Patria Airlangga, "Hakikat Penguasa Dalam Negara Hukum Demokratis," Cepalo 3, no. 1 (September 17, 2019): 110, https://doi.org/10.25041/cepalo.v3no1.1783.hlm. 2

2 Arief Gosita, Masalah Perlindungan Anak, , Bhuana Ilmu Populer, Jakarta, 2001, hlm. 23

3 Citrawati "Analisis Yuridis Putusan Pidana Pembinaan Terhadap Anak Pelaku Pencurian Dengan Pemberatan" Verstek," accessed July 9, 2020: 306-318 https://jurnal.uns.ac.id/verstek/article/view/33450/22046. hlm. 307.

${ }^{4}$ Romli Atmasasmita, 1983, Problem Kenakalan Anak-Anak Remaja, Armico, (Bandung: Armico), hlm 37.

${ }^{5}$ Mirta Diatri Reisasari, "Penjatuhan Sanksi Pidana Pelatihan Kerja Terhadap Anak Yang Berhadapan Dengan Hukum," IJCLC (Indonesian Journal of Criminal Law and Criminology), Vol. 10, no. 1 (July 27, 2020): 10-19, https://doi.org/10.18196/ijclc.1102. hlm 10.

${ }^{6}$ ali Fikri, "Analisis Yuridis Penyelesaian Perkara Disersi Yang Diputus Secara In Absentia Sebelum Jangka Waktu 6 Bulan (Studi Kasus Di Pengadilan Militer Iii-12 Surabaya)." Jurnal Novum. Vol. 2, No. 14, (2015):1-9. https://jurnalmahasiswa.unesa.ac.id/index.php/novum/article/view/23996/21936.
} 
penjuru Indonesia,dengan pemberitaan sangat eksplisit dan berulang-ulang. ${ }^{7}$ Dalam kasus seperti ini anak harus mendapat perlindungan khusus terhadap kepentingan fisik dan mentalnya. ${ }^{8}$ Fenomena meningkatnya perilaku tindak kekerasan yang dilakukan oleh anak tidak sama dengan usia pelaku sendiri. ${ }^{9}$ Posisi anak-anak dalam instrumen Hak Asasi Manusia (HAM) nasional dan internasional ditempatkan sebagai kelompok rentan yang harus diberlakukan istimewa, dan negara mempunyai tanggung jawab untuk menjamin pemenuhan hak-hak istimewa tersebut. ${ }^{10}$

Guna mengantisipasi hal tersebut diperlukan sistem hukum yang dapat mengakomodir kebutuhan saat ini yang sesuai dengan perkembangan zaman. Sebagaimana adagium latin yakni "Tempora mutantur nos et mutamur in illis" (Masyarakat akan berubah dimana zaman tersebut ikut berubah) adagium ini dipopulerkan dalam bukunya William Harrison yang berjudul "Description of England" (1577.170). ${ }^{11}$

Sistem hukum peradilan pidana terhadap anak yakni (sebagai pelaku) yang menjadi salah satu sistem yang mengalami perubahan sistem hukum karena sistem peradilan pidana anak saat ini telah diperbaharui dengan Undang-Undang Republik Indonesia Nomor 11 Tahun 2012 tentang Sistem Peradilan Pidana Anak, sehingga perlu dilakukan perubahan demi terciptanya rezim hukum yang baru, mengingat anak haruslah diperlakukan secara berbeda dengan orang dewasa. ${ }^{12}$ Beberapa kasus kejahatan pencurian sangat rawan dilakukan pada waktu malam hari, karena pada malam hari merupakan waktu yang tepat untuk melakukan aksi dimana masyarakat sedang lengah. Sehingga dalam kasus pencurian yang dilakukan oleh anak tidak jarang disertai dengan keadaan yang memberatkan untuk mempermudah aksinya. ${ }^{13}$ Dalam kasus-kasus seperti ini hakim mempunyai kebebasan yang mutlak dalam menjatuhkan suatu putusan. Kebebasan Hakim Tidak bissa di ganggu gugat oleh pihak manapun. Kebebasan Hakim untukk menjatuhkan putusan pidana harus berpedoman atas rasa keadilan terhadap semua yang terlibat dalam suatu perkara seperti terdakwa, korban, dan masyarakat. ${ }^{14}$

Sejak sistem peradilan pidana anak mulai diberlakukan di Indonesia, maka hal tersebut ikut merubah cara pandang hukum yang tadinya bersifat kaku dalam memberikan sanksi terhadap anak. Sebelumnya dalam memberikan sanksi terhadap anak masih menggunakan sistem pembalasan. Saat ini "pembalasan dengan setimpal tersebut" (ius talionis), berubah dengan paradigma hukum yang melakukan pendekatan yang bersifat pendekatan secara

\footnotetext{
${ }^{7}$ Laurensius Arliman Et Al., "Reformasi Penegakan Hukum Kekerasan Seksual Terhadap Anak Sebagai Bentuk Perlindungan Anak Berkelanjutan Reform Of Law Enforcement Of Sexual Violence To Children As The Form Of Sustainable Children Protection," Kanun Jurnal Ilmu Hukum 19, No. 2 (August 27, 2311): 305-26, Http://Www.Jurnal.Unsyiah.Ac.Id/Kanun. hlm. 307

${ }^{8}$ Friwina Magnesia Surbakti and Rizkan Zuliandi, "Penerapan Hukum Terhadap Anak Sebagai Pelaku Tindak Pidana Pencurian Dengan Kekerasan,” Journal of Education, Humaniora and Social Sciences (JEHSS) 2, no. 1 (August 6, 2019): 143-62, https://doi.org/10.34007/jehss.v2i1.58. hlm.144.

${ }^{9}$ Dimas Alfathan Et al., "Kajian Yuridis Pemidanaan Terhadap Anak Pelaku Tindak Pidana Pencurian Dengan Kekerasan (Studi Putusan Nomor 19/Pid.Sus-Anak/2018/ Pn Smg)," Diponegoro Law Journal, Vol. 8 (Program Studi S1 Ilmu Hukum, Fakultas Hukum, Universitas Diponegoro, July $\quad 31, \quad$ 2019): $143-162$ Https://Ejournal3.Undip.Ac.Id/Index.Php/Dlr/Article/View/25989.hlm. 1920

${ }^{10}$ Okky Chahyo et al., "Peran Balai Pemasyarakatan Pada Sistem Peradilan Pidana Anak Di Tinjau Dalam Perspektif Hak Asasi Manusia (The Role of Balai Pemasyarakatan on Juvenile Justice System Reviewed from Human Rights Perspective)," Jurnal HAM, vol. $\quad 8, \quad$ (December $15, \quad 2017$ ): 161-174, $\quad$ http://www.pikiranrakyat.com/bandungraya/2015/08/04/337054/sepuluh-ribu-anak-kiniberhadapan-dengan-hukum hlm. 162.

11 Muladi, 22 Januari 2015, Era Baru Sistem Peradilan Pidana Anak, http://www.pnpalopo.go.id/index.php/berita/artikel/163-era-baru-sistem-peradilan-pidana-anak diakses tanggal 22 Nopember 2019.

${ }_{12}$ M. Nasir Djamil, 2013, Anak Bukan Untuk Dihukum, (Jakarta : Sinar Grafika), hlm 4.

13 Andani Maya Sari and Budi Setiyanto, "Penerapan Sanksi Pidana Terhadap Anak," Jurnal Hukum Pidana Dan Penanggulangan Kejahatan, vol. 4, (September 1, 2015): 266-273 https://jurnal.uns.ac.id/recidive/article/view/40740. hm. 267.

${ }^{14}$ GD. Bagus Maesha Kumara, Anak Agung Sagung Laksmi Dewi, and Diah Gayatri Sudibya, "Penahanan Anak Yang Melakukan Tindak Pidana Pencurian Dengan Kekerasan (Studi Kasus Nomor: 6/Pid.Sus-Anak/2017/PN Dps)," Jurnal Analogi Hukum 1, no. 1 (December 17, 2019): 62-66, https://doi.org/10.22225/.1.1.1468.62-66.hlm.65
} 
kemanusiaan yang lebih mementingkan kemanfaatan dan masa depan anak. Toni Marshal mengatakan semua pihak turut berperan aktif dalam mencari jalan untuk menyelesaikan permasalahan yang menyangkut masa depan anak. ${ }^{15}$ Sudarto juga mengemukakan hal yang sama bahwa di dalam peradilan anak terdapat aktivitas pemeriksaan dan pemutusan perkara yang tertuju pada kepentingan anak, yaitu segala aktivitas yang dilakukan oleh polisi, jaksa, hakim dan pejabat lain, harus didasarkan pada suatu prinsip ialah demi kesejahteraan anak dan kepentingan anak. ${ }^{16}$

Pada Tanggal 31 Juli 2014 undang-undang sistem peradilan pidana anak baru berlaku efektif yang mana disebutkan dalam salah satu pasal penjatuhan pidana terhadap anak yang melakukan tindak pidana dapat dijatuhi hukuman berupa pemidanaan dan penindakan. Pemidanaan terhadap anak terdiri dari pidana dengan syarat, pelatihan kerja, pidana peringatan, pembinaan dalam lembaga, dan yang terakhir adalah penjara. Proses penyelesaian perkara anak yang terlibat masalah hukum, harusnya berbeda dengan orang dewasa. Prosedurnya harus dilakukan secara cermat, agar anak tetap mendapatkan perlindungan secara maksimal. ${ }^{17}$ Pada hakekatnya, segala bentuk penanganan terhadap anak yang melanggar hukum harus memprioritaskan kepentingan terbaik untuk anak. ${ }^{18}$

Wilayah Provinsi Lampung sendiri sudah terdapat LPKA Kelas II Bandar Lampung dan LPKS ABH Insan Berguna di Pesawaran. LPKA adalah Tempat anak dalam menempuh masa pemidanaannya, ${ }^{19}$ dan LPKS adalah sebuah tempat untuk menaungi anak nakal untuk dilakukan pembinaan agar menjadi anak yang lebih berdaya guna. ${ }^{20}$ Sebagai studi kasus yang diangkat oleh penulis dalam penelitian ini adalah mengenai putusan Nomor: 8/Pid.SusAnak/2016/PN.Kot yang diputus oleh Pengadilan Negeri Kota Agung di Tanggamus. Perkara tentang anak yang bernama Abdul Mukhlisin Als Ucin Bin Tholip (Alm) yang pada saat melakukan tindak pidana masih berumur 16 Tahun dan Irfan Suprihatin Bin Subandi yang pada saat melakukan tindak pidana masih berumur 14 Tahun dimana anak Abdul Mukhlisin Als Ucin Bin Tholip (Alm) dan anak Irfan Suprihatin Bin Subandi telah melakukan tindak pidana pencurian dengan pemberatan sebagaimana dalam tuntutan Jaksa yakni Pasal 363 (ayat) 2 KUHP. Penuntut Umum dalam tuntutannya terhadap anak menuntut agar anak Abdul Mukhlisin Als Ucin Bin Tholip (Alm) dan anak Irfan Suprihatin Bin Subandi atas perbuatan yang telah dilakukan, dipidana berupa pembinaan di dalam LPKA Kelas II Bandar lampung di Masgar selama 10 (sepuluh) bulan, tetapi hakim melalui putusannya menjatuhkan pidana berupa pidana pembinaan dalam lembaga kepada anak berupa kewajiban mengikuti program pembinaan di Pondok Pesantren Miftahul Huda yang beralamat di Desa Sinar Mulya Kecamatan Banyumas Kabupaten Pringsewu selama 7 (tujuh) bulan. Menurut penulis, hakim dalam memutus perkara tersebut harusnya mempertimbangkan hasil dari rekomendasi penelitian kemasyarakatan yang dengan kesimpulan apabila terbukti bersalah, maka dituntut dan diputus dengan pidana pembinaan dalam LPKA Kelas II Bandar lampung di Masgar. Hal ini sebagaimana dijelaskan dalam Undang-Undang Nomor 11 Tahun 2012 tentang Sistem

\footnotetext{
15 Muladi, 22 Januari 2015, Era Baru Sistem Peradilan Pidana Anak, http://www.pnpalopo.go.id/index.php/berita/artikel/163-era-baru-sistem-peradilan-pidana-anak diakses tanggal 22 Nopember 2019.

16 Wibowo, "Implikasi Berlakunya Undang-Undang Nomor 11 Tahun 2012 Tentang Sistem Peradilan Pidana Anak Terhadap Kelembagaan Dan Regulasi Pelaksana." Jurnal Legislasi Indonesia. Vol.13 No. 2,” (Accessed July 10, 2020 ): 121 133. Http://E-Jurnal.Peraturan.Go.Id/Index.Php/Jli/Article/View/107/Pdf.hlm. 122

17 Ismawati "Mekanisme Penyelesaian Perkara Anak Yang Berhadapan Dengan Hukum Pada Masyarakat Dayak Kanayatn (Kajian Perbandingan Terhadap Sistem Peradilan Pidana Anak)". Jurnal Dinamika Hukum. Vol. 13. No. 2. ( accessed July 10, 2020,): 198-209. http://www.dinamikahukum.fh.unsoed.ac.id/index.php/JDH/article/view/203/151 Hlm. 198.

18 maksum Hadi Putra, "Sanksi Pidana Terhadap Anak Yang Melakukan Pengulangan Tindak Pidana (Residive) Criminal Sanctions On Recidivist Children," Jurnal IUS Kajian Hukum Dan Keadilan, vol. 4, (August 10, 2016): 50-67. https://doi.org/10.12345/IUS.V4I2.344. hlm.50.

${ }^{19}$ M. Nasir Djamil, 2013, Anak Bukan Untuk Dihukum, (Jakarta : Sinar Grafika), hlm 167.

${ }^{20}$ ibid hlm 168.
} 
Peradilan Pidana Anak Pasal 60 ayat (3) yang menyebutkan bahwa sebelum menjatuhkan putusan hakim berkewajiban untuk melakukan pertimbangan terhadap laporan penelitian kemasyarakatan dan juga pembimbing kemasyarakatan.

Laporan yang dibuat oleh pembimbing kemasyarakatan yakni berupa penelitian yang dikaji secara analisis data dan lapangan mengenai anak, sehingga rekomendasi yang dibuat berdasarkan laporan penelitian kemasyarakatan terhadap anak diharapkan merupakan solusi yang bijak dalam penyelesaian kasus anak yang melakukan tindak pidana. Melihat perkembangan anak dewasa ini yang banyak berkonflik dengan hukum hal tersebut dikarenakan minimnya pengawasan yang diberikan oleh orang tua, peran orang tua dalam keluarga sangatlah penting untuk mendidik dan mengawasi perkembangan anaknya, di mana perkembangan anak memiliki kondisi kejiwaan yang labil sehingga cenderung melakukan tindakan yang agresif di luar kesadarannya. ${ }^{21}$

Selain itu dalam Undang-Undang Nomor 11 Tahun 2012 tentang Sistem Peradilan Pidana Anak Pasal 80 ayat (1) menjelaskan bahwa: Pelatihan kerja diselenggarakan oleh lembaga pembinaan di dalam lembaga atau pemerintah maupun swasta dapat menjadi penyelenggara. Sarana hukum pidana melalui sistem Peradilan Pidana termasuk Peradilan Pidana Anak yang dapat juga disebut sebagai Sidang Anak, bertugas dan berwenang memeriksa, memutus dan menyelesaikan perkara anak sebagaimana ditentukan dalam peraturan perundang-undangan yang berlaku. ${ }^{22}$

Sesuai dengan hasil dari rekomendasi hasil penelitian kemasyarakatan dan tuntutan dari penuntut umum yang menyebutkan apabila anak terbukti bersalah dituntut dan diputus dengan pidana pembinaan dalam LPKA Kelas II Bandar lampung di Masgar, dengan memperhatikan bahwa anak yang sudah dijatuhi hukuman agar ditempatkan di LPKA agar mendapat keterampilan, pendidikan, serta pembinaan hal ini sesuai dengan kemanfaatan anak agar tidak hilang haknya untuk memperoleh kesejahteraan. ${ }^{23}$ Tetapi hakim melalui putusannya memilih untuk yang menjatuhkan pidana berupa pidana pembinaan dalam lembaga kepada anak berupa kewajiban mengikuti program pembinaan di Pondok Pesantren Miftahul Huda daripada LPKA yang merupakan lembaga milik pemerintah yang diperuntukkan bagi anak untuk menjalani masa pidananya.

Berdasarkan latar belakang masalah di atas tersebut, penulis tertarik melakukan kajian mengenai: "Pertimbangan Hukum Hakim Dalam Penjatuhan Sanksi Pembinaan Terhadap Anak Pelaku Pencurian dengan Pemberatan (Analisis Putusan Nomor: 8/Pid.SusAnak/2016/Pn.Kot)"

\section{B. Rumusan Masalah}

Adapun rumusan masalah dalam penulisan jurnal karya ilmiah ini terbagi tiga yakni:

1. Apakah dasar pertimbangan hukum hakim dalam menjatuhkan pidana pembinaan terhadap anak pelaku tindak pidana pencurian dengan pemberatan pada putusan Nomor: 8/Pid.Sus-Anak/2016/PN.Kot?

2. Apakah putusan Nomor: 8/Pid.Sus-Anak/2016/PN.Kot telah sesuai dengan tuntutan jaksa penuntut umum?

3. Bagaimana mekanisme pelaksanaan putusan Nomor: 8/Pid.Sus-Anak/2016/PN.Kot?

\footnotetext{
${ }^{21}$ Ni Made Et Al., "Implementasi Undang-Undang Nomor 11 Tahun 2012 Tentang Sistem Peradilan Pidana Anak Terhadap Curanmor Yang Dilakukan Oleh Anak Di Kabupaten Buleleng (Studi Kasus Perkara Nomor: B/346/2016/Reskrim)," Jurnal Komunitas Yustisia, Vol. 2, (February 28, 2019): 1-13. Https://Bulelengkab.Bps.Go.Id.hlm.2

${ }^{22}$ Raodathul Jannah, "Pertanggungjawaban Pidana Oleh Anak Pelaku Bullying," LEX CRIMEN, vol. 7, (July 4, 2018): 105-

113. https://ejournal.unsrat.ac.id/index.php/lexcrimen/article/view/20008/19616. hlm.107.

${ }^{23}$ Ibid hlm 167.
} 


\section{Pembahasan}

\section{Dasar Pertimbangan Hukum Hakim Dalam Menjatuhkan Pidana Pembinaan Terhadap Anak Pelaku Tindak Pidana Pencurian Dengan Pemberatan Pada Putusan Nomor: 8/Pid.Sus-Anak/2016/PN.Kot}

Menurut Ratriningtyas Ariani selaku Hakim Pengadilan Negeri Kota Agung demi tegaknya kepastian hukum, keadilan, dan juga kemanfaatan bagi anak sebaiknya hakim sebelum menjatuhkan sanksi hukuman wajib menggali nilai-nilai yang hidup dalam masyarakat dan juga faktor kemanfaatan dan mempertimbangkan masa depan anak sehingga putusan yang dipertimbangkan pun menjadi berkualitas dan bukan hanya mengedepankan aspek pembalasan semata.

Berdasarkan hasil penelitian yang dilakukan oleh peneliti terhadap putusan Nomor: 8/Pid.Sus-Anak/2016/PN.Kot yang diadili oleh hakim dengan menempatkan para anak ke dalam program pembinaan di Pondok Pesantren Miftahul Huda yang beralamat di Desa Sinar Mulya Kecamatan Banyumas Kabupaten Pringsewu selama 7 (tujuh) bulan daripada pidana pembinaan dalam Lembaga di LPKA sebagaimana dimaksud dalam Pasal 71 ayat (1) huruf d UU RI No 11 Tahun 2012 tentang SSPA.

Hal tersebut dikarenakan hakim menilai dalam pertimbangannya bahwasannya kedua terdakwa tersebut melakukan tindak pidana berupa pencurian dalam keadaan memeberatkan dikarenakan bukan karena faktor kejahatan dalam dirinya lebih dominan karena faktor dominan kenakalan remaja, oleh sebab itu berdasarkan hal tersebut hakim contra legem dengan undang-undang peradilan anak dan juga mengabaikan hasil penelitian kemasyarakatan terhadap Abdul Mukhlisin Als Ucin Bin Tholip (Alm) dan Irfah Suprihatin Bin Subandi No Reg Litmas: 71/Lit.Pol./KA/III/2016 Tanggal 22 Maret 2016, tuntutan penuntut umum, permohonan dari para anak dan orang tua para anak serta, asas dari sistem peradilan anak.

Peneliti mengamati bahwasannya dalam pertimbangan hakim tersebut lebih kepada pertimbangan yang bersifat pembinaan daripada pemidanaan oleh karena itu hakim menempatkan kedua anak di Pondok Pesantren selama 7 (Tujuh) bulan karena hakim melihat kedua anak tersebut masih bisa diperbaiki mentalnya dan juga dengan memberikan kesempatan kepada kedua anak tentunya akan memberikan perlindungan bagi hak-haknya dan juga menyelamatkan masa depannya yang mana banyak faktor kemudharatan apabila kedua anak tersebut ditempatkan di Lembaga Pembinaan Khusus Anak. Diharapkan dengan ditempatkan di Pondok Pesantren tersebut anak yang dibina dalam pondok tersebut mampu mengubah sudut pandang dan dapat memahami nilai-nilai agama yang membawa ke arah lingkungan yang lebih baik atau bernilai positif.

Hakim dapat berbeda pandangannya dengan Jaksa Penuntut Umum karena hakim adalah profesi yang tidak memihak (imparsialitas) bebas (independent) dan tidak terikat kepada bunyi undang-undang artinya hakim dapat saja menciptakan undang-undang dan menemukan undang-undang (rechtvinding), oleh karena itulah hakim dalam mengadili perkara memiliki independensi.

Jiwa hakim dalam mengadili sebuah perkara haruslah memiliki jiwa kebebasan dalam mengambil sebuah keputusan dan bebas dari intervensi. Hal ini penting karena hakim dalam mengadili suatu perkara tentunya harus terlepas dari pengaruh lingkungan, kekuasaan, dan juga politik. Hakim sebagai penentu keadilan dalam melihat suatu perkara didasarkan bukti serta fakta yang dihadirkan di dalam persidangan yang berasaskan hukum.$^{24}$

\footnotetext{
${ }^{24}$ Ahmad Rifai, 2010, Penemuan Hukum oleh Hakim dalam Persfektif Hukum Progresif, Sinar Grafika, Jakarta, hlm.103.
} 
Hakim dinilai bukan dari kepatuhan dirinya dalam mengikuti aturan yang sesuai dengan bunyi undang-undang, akan tetapi lebih kepada jiwa keberanian memutus dengan berdasarkan hati nurani beserta keyakninannya terhadap suatu perkara yang dilihatnya akan berpotensi menciderai nilai-nilai keadilan. ${ }^{25}$ Undang-Undang Kekuasaan Kehakiman dibuat bukan untuk mengekang kebebasan hakim dalam berperkara akan tetapi lebih memerdekakan hakim sebagai sebuah profesi yang dituntut tanggungjawab mencari nilai-nilai keadilan dalam masyarakat, oleh karena itu hakim diwajibakan untuk memahami, mengikuti dan menggali nilai-nilai yang hidup dalam masyarakat bukan berpatokan kepada bunyi undang-undang semata. Hal ini agar hakim memiliki jiwa hukum yang progresif dalam mengadili suatu perkara ketika dihadapkan hukum tersebut tidak sesuai dengan rasa keadilan dalam masyarakat, atau tidak adanya hukum yang mengatur terhadap perbuatan tersebut sehingga mengakibatkan kekosongan hukum (recht vacum) hakim dapat menciptakan hukum atau menemukan hukum.

Sebagai contoh dalam perkara dengan putusan Nomor: 8/Pid.Sus-Anak/2016/PN.Kot yang mana hakim melalui putusannya lebih memilih untuk menjatuhkan pidana berupa pidana pembinaan dalam lembaga kepada anak berupa kewajiban mengikuti program pembinaan di Pondok Pesantren Miftahul Huda daripada LPKA yang merupakan lembaga milik pemerintah yang diperuntukkan bagi anak untuk menjalani masa pidananya.

Berkaca dari teori pertimbangan hakim tersebut hakim dalam mengadili perkara Nomor : 8/Pid.Sus-Anak/2016/PN.Kot melihat dari kontekstual Pasal 71 Ayat (1) butir b UU SSPA. Hal tersebut memberikan alternatif bagi penegak hukum dalam memberikan sanksi pidana kepada anak yakni dapat berupa pidana pokok yang berupa pidana peringatan dan juga pidana dengan syarat yakni bisa pidana pembinaan di luar lembaga. Maupun di dalam lembaga baik yang diselenggarakan oleh pemerintah atau swasta.

Menurut peneliti dalam hal ini kategori pondok pesantren sebagaimana diatur dalam pada Undan-Undang Nomor 18 Tahun 2019 tentang Pesantren, memang tidak jelas apakah lembaga tersebut masuk dalam lembaga yang diselenggarakan oleh pemerintah atau swasta, akan tetapi apapun itu alasannya menurut peneliti bahwasanya majelis hakim lebih mempertimbangkan kedua anak tersebut ditempatkan dan dibina di dalam lembaga berupa kewajiban mengikuti program pembinaan di Pondok Pesantren Miftahul Huda lebih kepada aspek pembinaan yang bersifat mendidik baik itu dari segi spritual, rohani dan juga mental daripada ditempatkan di LPKA yang masih jauh dalam pembinaan dari segi keagamaannya, apalagi anak yang masuk dalam LPKA tersebut masyarakat masih berpandangan skeptis karena anak yang dibina ditempat tersebut masih dikategorikan sebagai anak yang bermasalah dengan hukum.

\section{Apakah Putusan Nomor : 8/Pid.Sus-Anak/2016/PN.Kot Telah Sesuai Dengan Tuntutan Jaksa Penuntut Umum}

Tindakan yang dilakukan oleh anak mengakibatkan kerugian bagi korbannya. Tetapi kerugian tersebut tidak sampai membuat nyawa orang lain melayang ataupun kerugian tersebut tidak berdampak secara signifikan terhadap korban. Didalam amar putusan barang bukti berupa barang curian tersebut unitnya masih ada dan unit tersebut telah dikembalikan kepada korban, sehingga dalam hal ini hakim memilih opsi untuk membina dan memperhatikan masa depan para anak yang berhadapan dengan hukum. Pada prinsipnya hakim berpendapat apabila masih bisa dilakukan perbaikan kepada para anak tersebut akan lebih baik dampaknya daripada diberikan sanksi pemidanaan yang lebih berat dikhawatirkan jutru akan menghilangkan hak-haknya serta masa depannya sebagai anak.

${ }^{25}$ Manan, Bagir, 2000, Peran Hakim Dalam Dekolonialisasi Hukum dalam Wajah Hukum di Era Reformasi, Bandung: Citra Aditya Bakti. 
Berdasarkan hal diatas tersebut menurut penulis dari hasil penelitian yang dilakukan berbicara mengenai konteks keadilan tidak ada yang bisa mencapai derajat keadilan yang paling tinggi kecuali hanya Tuhan, paling tidak hakim yang mengadili perkara ini sebagai manusia biasa sudah memberikan proporsi keadilan dan juga keseimbangan bagi para anak.

Berdasarkan hasil penelitian yang dilakukan penulis bahwa sesuai dengan teori keadilan bahwasanya rasa keadilan substansif telah dipegang oleh hakim, yang dimaksud dengan keadilan substansif adalah keadilan yang berdasarkan aturan-aturan hukum. ${ }^{26}$ Keadilan ini diberikan dengan tanpa melihat kesalahan-kesalahan secara prosedural yang tidak berpengaruh pada hak-hak substantif. Sesuatu bisa saja secara subtansinya melanggar keadilan serta secara materiil disalahkan padahal secara formal prosedural adalah benar demikian juga sebaliknya yaitu sesuatu hal bisa saja secara substansi dan materiil melanggar keadilan tetapi hal tersebut dibenarkan apabila secara formal adalah salah.

Makna dari keadilan substansif sendiri bermakna hakim bisa mengabaikan peraturan perundang-undangan jika peraturan tersebut mengabaikan rasa keadilan. hal ini berarti hakim dengan kekuasaan kehakiman dapat menciptakan hukum baru guna mencapai rasa keadilan di masyarakat seperti halnya dengan Putusan Nomor: 8/Pid.Sus-Anak/2016/Pn.Kot hakim sudah berusaha memberikan keadilan yakni kepada para anak yakni dengan tetap memperhatikan undang-undang dengan memberikan sanksi pidana terhadap konsekuensi hukum yang dilakukan oleh para anak akan tetapi metode pemberian sanksinya dengan cara pidana melalui sarana pembinaan di pondok pesantren sehingga keadilan tersebut tercermin dalam putusan tersebut dengan tetap memperhatikan norma substansif yang dilanggar akan tetapi tidak mengabaikan keadilan didalamnya.

\section{Mekanisme Pelaksanaan Putusan Nomor : 8/Pid.Sus-Anak/2016/PN.Kot}

Mekanisme pelaksanaan putusan Nomor: 8/Pid.Sus-Anak/2016/Pn.Kot hakim menjatuhkan pidana pembinaan dalam lembaga kepada Anak 1 Abdul Mukhlisin Als Ucin Bin Tholip (Alm), anak 2 Irfan Suprihatin Bin Subandi berupa kewajiban mengikuti program pembinaan di Pondok Pesantren Miftahul Huda sehingga pembinaan tersebut mengikuti metode pembelajaran pesantren dengan metode pembinaan umum yang mencakup pembinaan perilaku memberi motivasi, mengajak melakukan perbuatan baik kepada santri, dengan cara mempelajari perilaku sesuai dengan tuntunan Al-Quran dan Sunnah, memberlakukan tata tertib yang disiplin, belajar tingkah laku dari para alim ulama yang diajarkan Rasul dan para sahabat, dan melakukan kegiatan keagamaan untuk mendidik mental para santri serta melakukan evaluasi berkala, berkaca dari pertimbangan hakim yang lebih memilih Pondok Pesantren Miftahul Huda karena hakim yakin dengan pertimbangannya tersebut dengan memasukkan para anak ke pondok pesantren lebih bermanfaat daripada harus dilakukan upaya pemidanaan di LPKA karena dari sisi kemanfaatannya pondok pesantren lebih banyak menekankan fondasi agama daripada pembinaan di LPKA sehingga dilihat sisi kemanfaatannya lebih efektif memberikan efek jera dan pembinaan ahlak dan mental.

Pertimbangan hakim tersebut lebih kepada pertimbangan yang bersifat tujuan pemidanaan yang mana dalam teori pemidanaan menyebutkan ada berbagai teori yakni teori absolut atau teori pembalasan, teori relatif atau teori tujuan dan teori gabungan. Salah satu teori yang lebih dominan digunakan hakim dalam memberikan sanksi pidana kepada para anak adalah teori relatif. Sesuai dengan teori relatif ini menekankan bahwa tujuan dilakukan pemidanaan bukan saja untuk memberikan efek jera kepada pelaku, akan tetapi lebih kepada memberikan tujuan-tujuan memperbaiki sifat para anak yang menekankan pembinaan agar setelah keluar

${ }^{26}$ Zain Al-Muhtar, Op.cit 
dari pondok pesantren dapat menjadi orang yang lebih baik dan diterima masyarakat di lingkungannya.

Berkaca dari pertimbangan hakim yang lebih memilih Pondok Pesantren Miftahul Huda karena majelis hakim yakin dengan pertimbangannya tersebut dengan memasukkan para anak ke pondok pesantren lebih bermanfaat daripada harus dilakukan upaya pemidanaan di LPKA karena dari sisi kemanfaatannya pondok pesantren lebih banyak menekankan pondasi agama daripada pembinaan di LPKA sehingga dilihat sisi kemanfaatannya lebih efektif memberikan efek jera dan pembinaan ahlak dan mental.

\section{Saran}

Adapun saran yang dapat disampaikan oleh penulis yakni:

1. Sebaiknya Jaksa Penuntut Umum lebih memperhatikan aspek kemanfaatan dalam memberikan sanksi pemidanaan kepada anak, alternatif pembinaan secara spritual menjadi jalan untuk memperbaiki akhlak anak sehingga tuntutan Jaksa Penuntut Umum tidak hanya mengenai sanksi represif yang bersifat hukuman kurungan akan tetapi lebih dioptimalkan kepada hal yang menyelamatkan masa depan sang anak;

2. Sebaiknya pertimbangan hakim kedepannya nanti harus bisa mencerminkan keadilan dan juga langkah yang progresif khususnya dalam pemberian sanksi terhadap anak yang berhadapan dengan hukum.

\section{Daftar Pustaka}

A. Buku

Ahmad Irzal Fardiansyah, Suseno Sigid, Rukmini Mien, and Sulistiani Lies, 'Pengakuan Terhadap Hukum Pidana Adat Di Indonesia', Jurnal Bina Mulya Hukum, 4.1 (2019), 112 29.

Arief Gosita, 2001, Masalah Perlindungan Anak, , Bhuana Ilmu Populer, Jakarta.

Bagir Manan, 2000, Peran Hakim Dalam Dekolonialisasi Hukum dalam Wajah Hukum di Era Reformasi, Bandung: Citra Aditya Bakti.

Romli Atmasasmita, 1983, Problem Kenakalan Anak-Anak Remaja, Armico, Bandung, Armico.

M. Nasir Djamil, 2013, Anak Bukan Untuk Dihukum, Jakarta : Sinar Grafika.

Muladi, 22 Januari 2015, Era Baru Sistem Peradilan Pidana Anak, http://www.pnpalopo.go.id/index.php/berita/artikel/163-era-baru-sistem-peradilan-pidana-anak diakses tanggal 22 Nopember 2019.

Ahmad Rifai, 2010, Penemuan Hukum oleh Hakim dalam Persfektif Hukum Progresif, Sinar Grafika, Jakarta.

B. Jurnal

Airlangga, shandi patria. "Hakikat Penguasa Dalam Negara Hukum Demokratis." Cepalo 3, no. 1, september 17, 2019: 1-10. Https://doi.org/10.25041/cepalo.v3no1.1783.

Alfathan, dimas, sinatrya tambunan, umi rozah, a $m$ endah, and sri astuti. "Kajian Yuridis Pemidanaan Terhadap Anak Pelaku Tindak Pidana Pencurian Dengan Kekerasan (Studi Putusan Nomor 19/Pid.Sus-Anak/2018/ Pn Smg)." Diponegoro law journal, vol. 8 (program studi s1 ilmu hukum, fakultas hukum, universitas diponegoro, july 31, 2019): 143-162 https://ejournal3.undip.ac.id/index.php/dlr/article/view/25989.

Ali Fikri, "Analisis Yuridis Penyelesaian Perkara Disersi Yang Diputus Secara In Absentia Sebelum Jangka Waktu 6 Bulan (Studi Kasus Di Pengadilan Militer Iii-12 Surabaya)." Jurnal Novum. Vol. 2, 20 No. 14, 2015:1-9. https://jurnalmahasiswa.unesa.ac.id/index.php/novum/article/view/23996/21936. 
Andani Maya Sari and Budi Setiyanto, "Penerapan Sanksi Pidana Terhadap Anak," Jurnal Hukum Pidana Dan Penanggulangan Kejahatan, vol. 4, September 1, 2015: 266-273 https://jurnal.uns.ac.id/recidive/article/view/40740.

Arliman, laurensius, s stih, padang; aphtn-han, and sumatera barat. "Reformasi Penegakan Hukum Kekerasan Seksual Terhadap Anak Sebagai Bentuk Perlindungan Anak Berkelanjutan Reform Of Law Enforcement Of Sexual Violence To Children As The Form Of Sustainable Children Protection." Kanun jurnal ilmu hukum. Vol. 19, no. 2, august 27, 2311: 305-26. Http://www.jurnal.unsyiah.ac.id/kanun.

Bagir Manan, 2000, Peran Hakim Dalam Dekolonialisasi Hukum dalam Wajah Hukum di Era Reformasi, Bandung: Citra Aditya Bakti.

Citrawati "Analisis Yuridis Putusan Pidana Pembinaan Terhadap Anak Pelaku Pencurian Dengan Pemberatan" Verstek," accessed july 9, 2020: 306-318 https://jurnal.uns.ac.id/verstek/article/view/33450/22046.

Chahyo, okky, nugroho, et al. "Peran Balai Pemasyarakatan Pada Sistem Peradilan Pidana Anak Di Tinjau Dalam Perspektif Hak Asasi Manusia (The Role Of Balai Pemasyarakatan On Juvenile Justice System Reviewed From Human Rights Perspective)." Jurnal ham. Vol. 8, december 15, 2017: 161-174. Http://www.pikiranrakyat.com/bandungraya/2015/08/04/337054/sepuluh-ribu-anakkiniberhadapan-dengan-hukum.

Ismawati "Mekanisme Penyelesaian Perkara Anak Yang Berhadapan Dengan Hukum Pada Masyarakat Dayak Kanayatn (Kajian Perbandingan Terhadap Sistem Peradilan Pidana Anak)". Jurnal Dinamika Hukum. Vol. 13. No. 2, accessed July 10, 2020: 198-209. http://www.dinamikahukum.fh.unsoed.ac.id/index.php/JDH/article/view/203/151.

Kumara, gd. Bagus maesha, anak agung sagung laksmi dewi, and diah gayatri sudibya. "Penahanan Anak Yang Melakukan Tindak Pidana Pencurian Dengan Kekerasan (Studi Kasus Nomor: 6/Pid.Sus-Anak/2017/Pn Dps)." Jurnal analogi hukum 1, no. 1, december 17, 2019: 62-66. Https://doi.org/10.22225/.1.1.1468.62-66.

Made, ni, ita ariani, ni putu, rai yuliartini, dewa gede, and sudika mangku. "Implementasi Undang-Undang Nomor 11 Tahun 2012 Tentang Sistem Peradilan Pidana Anak Terhadap Curanmor Yang Dilakukan Oleh Anak Di Kabupaten Buleleng (Studi Kasus Perkara Nomor: B/346/2016/Reskrim).” Jurnal Komunitas Yustisia. Vol. 2, February 28, 2019. https://bulelengkab.bps.go.id.

Muladi, 22 Januari 2015, Era Baru Sistem Peradilan Pidana Anak, http://www.pnpalopo.go.id/index.php/berita/artikel/163-era-baru-sistem-peradilan-pidana-anak diakses tanggal 22 Nopember 2019.

Putra, Maksum Hadi. "Sanksi Pidana Terhadap Anak Yang Melakukan Pengulangan Tindak Pidana (Residive) Criminal Sanctions On Recidivist Children.” Jurnal IUS Kajian Hukum Dan Keadilan. Vol. 4, August 10, 2016. https://doi.org/10.12345/IUS.V4I2.344.

Raodathul Jannah, "Pertanggungjawaban Pidana Oleh Anak Pelaku Bullying," LEX CRIMEN, vol. $7, \quad$ July $4, \quad$ 2018: https://ejournal.unsrat.ac.id/index.php/lexcrimen/article/view/20008/19616. hlm.107.

Reisasari, Mirta Diatri, and Kata Kunci. "Penjatuhan Sanksi Pidana Pelatihan Kerja Terhadap Anak Yang Berhadapan Dengan Hukum." IJCLC (Indonesian Journal of Criminal Law and Criminology) 10, no. 1, July 27, 2020: 10-19. https://doi.org/10.18196/ijclc.1102.

Surbakti, Friwina Magnesia, and Rizkan Zuliandi. "Penerapan Hukum Terhadap Anak Sebagai Pelaku Tindak Pidana Pencurian Dengan Kekerasan." Journal of Education, Humaniora and Social Sciences (JEHSS) 2, no. 1 (August 6, 2019): 143-62. https://doi.org/10.34007.

Wibowo, "Implikasi Berlakunya Undang-Undang Nomor 11 Tahun 2012 Tentang Sistem Peradilan Pidana Anak Terhadap Kelembagaan Dan Regulasi Pelaksana." jurnal legislasi indonesia. Vol.13 no. 2," (accessed july 10, 2020): 121-133. Http://ejurnal.peraturan.go.id/index.php/jli/article/view/1. 
C. Undang-undang

Undang-Undang Dasar Republik Indonesia Tahun 1945.

Undang-Undang Nomor 1 Tahun 1946 Jo Undang-Undang Nomor 73 Tahun 1958 tentang pemberlakukan Kitab Undang-Undang Hukum Pidana (KUHP).

Undang-Undang Nomor 4 Tahun 1979 tentang Kesejahteraan Anak.

Undang-Undang Nomor 8 Tahun 1981 tentang Kitab Undang-Undang Hukum Acara Pidana (KUHAP).

Undang-Undang Nomor 39 Tahun 1999 tentang Hak Asasi Manusia.

Undang-Undang Nomor 48 Tahun 2009 tentang Kekuasaan Hakim.

Undang-Undang Republik Indonesia Nomor 17 Tahun 2016 tentang Penetapan Peraturan Pemerintah Pengganti Undang-Undang Nomor 1 Tahun 2016 tentang Perubahan Kedua Atas Undang-Undang Nomor 23 Tahun 2002 tentang Perlindungan Anak Menjadi Undang-Undang. Undang-Undang Republik Indonesia Nomor 11 Tahun 2012 tentang Sistem Peradilan Pidana Anak. 
